\title{
WYBRANE ASPEKTY OCENY ODPORNOŚCI OGNIOWEJ PRZESZKLONYCH ELEMENTÓW ODDZIELENIA PRZECIWPOŻAROWEGO
}

\begin{abstract}
Coraz większe wykorzystanie szkła we współczesnym budownictwie ma swoje uzasadnienie. Jest to materiał pozwalający na kształtowanie powierzchni użytkowych z maksymalnym wykorzystaniem światła dziennego, a współczesne technologie umożliwiają eliminację niekorzystnych wpływów atmosferycznych, zapewniając jednocześnie niezbędny komfort i intymność. Ponadto, nowoczesne elewacje wykorzystujące szkło, pozwalają również na efektywne energetycznie rozwiązania, łącznie z pozyskiwaniem energii z promieniowania słonecznego. Budynki, w tym elementy przeszklone oprócz normalnych warunków użytkowania, w określonym zakresie muszą również spełniać wymagania ogniowe. O ile w przypadku wielu rozwiązań np. murowych wymagania konstrukcyjne, osłonowe i pożarowe są spełnione niejako równolegle, to w przypadku elementów przeszklonych należy stosować specjalne rozwiązania, które umożliwiają uzyskanie odpowiedniej klasy odporności ogniowej, reakcji na ogień, klasy dymoszczelności, czy też spełnienie wymagań związanych z rozprzestrzenianiem ognia przez elementy.
\end{abstract}

Słowa kluczowe: ogniochronne przegrody przeszklone, ściany osłonowe, drzwi przeciwpożarowe, drzwi dymoszczelne, przeszklone ściany działowe, świetliki, odporność ogniowa, dymoszczelność

\section{Wprowadzenie}

Wśród elementów przeszklonych charakteryzujących się odpornością ogniową, w budownictwie najczęstsze zastosowanie mają ściany działowe [1]-[4], ściany osłonowe [5]-[8], drzwi [9]-[12] i okna [13], [14] oraz świetliki [15], [16]. Pomimo odmiennych funkcji jakie one pełnią w budynkach, uwzględniając problematykę bezpieczeństwa pożarowego muszą spełnić podobne kryteria. Najczęściej należą do nich szczelność, izolacyjność ogniowa oraz promieniowanie, a w przypadku elementów poziomych dodatkowo uwzględnia się nośność ogniową.

${ }^{1}$ Autor do korespondencji / corresponding author: Paweł Sulik, Instytut Techniki Budowlanej, Zakład Badań Ogniowych, ul. Ksawerów 21 budynek A, 02-656 Warszawa; tel. 225664210; p.sulik@itb.pl

2 Bartłomiej Sędłak, Instytut Techniki Budowlanej, Zakład Badań Ogniowych, ul. Ksawerów 21, budynek A, 02-656 Warszawa; tel. 225664494; b.sedłak@itb.pl 
Przez szczelność ogniową (E) rozumie się zdolność elementu konstrukcji, który pełni funkcję oddzielającą do wytrzymania oddziaływania ognia tylko $\mathrm{z}$ jednej strony bez przeniesienia ognia na stronę nienagrzewaną $\mathrm{w}$ wyniku przeniknięcia płomieni lub gorących gazów. Szczelność ogniową podczas badania sprawdza się za pomocą szczelinomierzy, tamponu bawełnianego lub wizualnie i uznaje się, że została utracona, gdy:

- na nienagrzewanej powierzchni elementu próbnego pojawi się ogień ciągły trwający dłużej niż $10 \mathrm{~s}$,

- tampon bawełniany ulegnie zapaleniu w czasie 30 sekund od momentu przyłożenia go do elementu próbnego,

- w wyniku działania ognia powstanie szczelina przekraczająca dopuszczalne wymiary.

$\mathrm{Na}$ rysunku 1. przedstawiono elementy próbne przeszklonych ścian działowych, które utraciły szczelność ogniową.
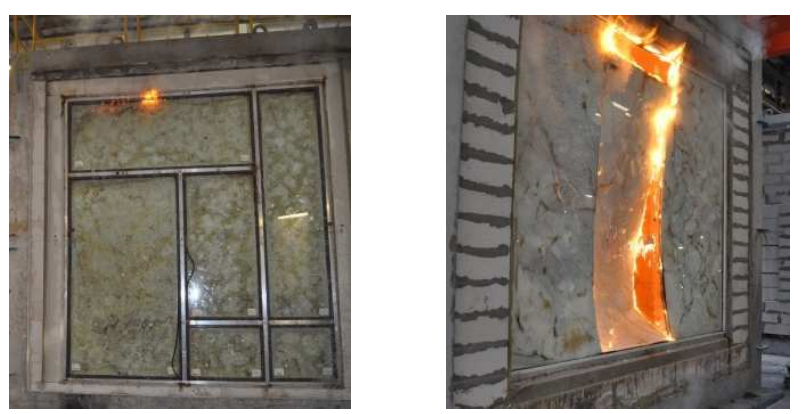

Rys. 1. Widok nienagrzewanej powierzchni elementu próbnego przeszklonej ściany działowej w momencie przekroczenia kryterium szczelności ogniowej. Autor: ITB

Fig. 1. The view of the unexposed surface of glazed partition test specimen when the fire integrity criterion is exceeded. Author: ITB

Izolacyjność (I) ogniowa to zdolność danego elementu, będącego oddzielającym elementem konstrukcji budowlanej, poddanego działaniu ognia $\mathrm{z}$ jednej strony, do ograniczenia przyrostu temperatury na powierzchni nienagrzewanej powyżej danego poziomu. Izolacyjność ogniowa weryfikowana jest za pomocą termoelementów powierzchniowych mocowanych do badanego elementu za pomocą kleju odpornego na temperaturę. Termoelementy rozmieszczone są w konkretnych miejscach, opisanych w normach badawczych. Dodatkowo laboratorium badawcze musi być wyposażone w termoelement ruchomy umożliwiający pomiar temperatury w dowolnym miejscu elementu próbnego, w którym wystąpi podejrzenie o przekroczeniu kryterium izolacyjności ogniowej (np. wyraźne zaciemnienie, widoczne zaczerwienienie świadczące o wzroście temperatury). Przykładowo, w przypadku przeszklonych ścian działowych maksymalny przyrost temperatury $\mathrm{w}$ danym punkcie ograniczony jest do $180 \mathrm{~K}$, a średni 
przyrost temperatury do $140 \mathrm{~K}$. Pomiar średniej temperatury prowadzony jest na przeszkleniach oraz panelach nieprzeziernych, natomiast pomiar temperatury maksymalnej prowadzony jest na profilach, jak również w normowej odległości np. $150 \mathrm{~mm}$ od krawędzi swobodnej oraz w określonych miejscach przeszkleń (lub paneli) o największych wymiarach. Na rysunkach 2 zaprezentowano przykładowe przyrosty temperatur na nienagrzewanej powierzchni największych przeszkleń elementów próbnych ścian działowych (linią ciągłą oznaczono wskazania termoelementów do pomiaru temperatury średniej, a linią przerywaną termoelementy do pomiaru temperatury maksymalnej umieszczone $20 \mathrm{~mm}$ od krawędzi elementu obramowania).
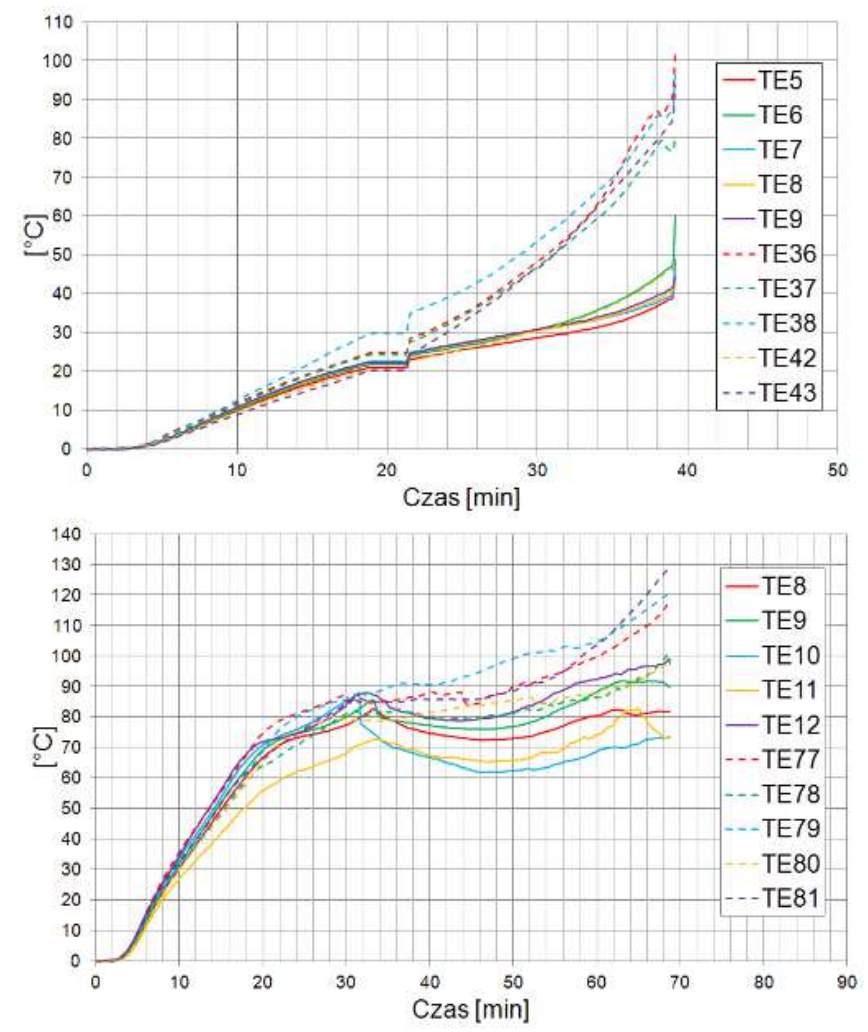

Rys. 2. Przykładowy wykres przyrostów temperatury na nienagrzewanej powierzchni największego przeszklenia elementu próbnego ściany działowej (szyba zespolona, linią ciągłą oznaczono wskazania termoelementów do pomiaru temperatury średniej a linią przerywaną termoelementy do pomiaru temperatury maksymalnej umieszczone $20 \mathrm{~mm}$ od krawędzi elementu obramowania). Autor: ITB

Fig. 2. Example graph of temperature rise on unexposed surface of largest glazing in glazed partition test specimen (coupled glass unit; the solid line indicates the temperature on thermocouples for measuring the average temperature rise and the dashed line temperature on thermocouples for measuring the maximum temperature placed $20 \mathrm{~mm}$ from the edge of the framing member). Author: ITB 
Kolejnym parametrem, często weryfikowanym w przypadku elementów przeszklonych jest promieniowanie (W), rozumiane jako zdolność elementu, pełniącego funkcję oddzielającą do wytrzymania oddziaływania ognia tylko z jednej strony tak, aby ograniczyć prawdopodobieństwo przeniesienia ognia w wyniku znaczącego wypromieniowania ciepła albo poprzez element albo $\mathrm{z}$ jego powierzchni nienagrzewanej do sąsiadujących materiałów w pomieszczeniu nie objętym pożarem. Promieniowanie oceniane jest na podstawie czasu, w którym maksymalna wartość promieniowania mierzonego w odległości $1 \mathrm{~m}$ od geometrycznego środka elementu próbnego nie przekracza $15 \mathrm{~kW} / \mathrm{m}^{2}$. Na rysunku 3. przedstawiono przykładowy wykres promieniowania dla przeszklonej ściany działowej (W1 - pomiar w odległości $1 \mathrm{~m}$ od geometrycznego środka elementu próbnego, W2 - pomiar w odległości $1 \mathrm{~m}$ od geometrycznego środka największej tafli szklanej w układzie pionowym, W3 - pomiar w odległości $1 \mathrm{~m}$ od geometrycznego środka największej tafli szklanej w układzie poziomym). Opisany na tym wykresie pomiar promieniowania sporządzony został dla elementu próbnego wyposażonego w specjalne szyby izolacyjne (przewidziane do stosowania w ścianach o klasie EI) [17], [18], dlatego też wartość promieniowania jest znikoma.

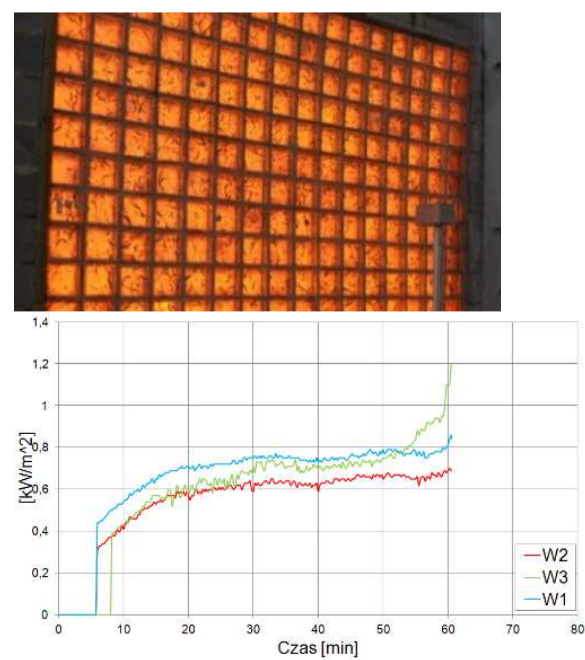

Rys. 3. Góra: Widok nienagrzewanej powierzchni elementu próbnego ściany działowej z pustaków szklanych w trakcie badania, przed elementem ustawione urządzenie do pomiaru poziomu promieniowania; dół: wykres promieniowania dla elementu próbnego przeszklonej ściany działowej (W1, W2, W3 - pomiary promieniowania $\mathrm{w}$ odległości $1 \mathrm{~m}$ od charakterystycznych punktów pomiarowych usytuowanych na elemencie próbnym). Autor: ITB

Fig. 3. Top: The view of the unexposed surface of glass block made partition test specimen, during the fire resistance test, in front of the element device for radiation measurements is set, bottom: graph of the radiation level for glazed partition test specimen (W1, W2, W3 - radiation measurements in $1 \mathrm{~m}$ distance from the characteristic measuring points located on the test specimen). Author: ITB 
Ostatnim z powszechnie występujących kryteriów jest nośność ogniowa (R), którą uwzględnia się w przeszklonych elementach poziomych i nachylonych. Jest to zdolność elementu konstrukcji do wytrzymania oddziaływania ognia przy określonych oddziaływaniach mechanicznych, na jedną lub więcej powierzchni, przez określony czas, bez utraty właściwości nośnych; w przypadku poziomych elementów przeszklonych, będących elementami zginanymi oceniana jest na podstawie prędkości deformacji (prędkości ugięcia) i stanu granicznego rzeczywistej deformacji (ugięcia) przy danym poziomie wytężenia konstrukcji.

\section{Wyposażenie do weryfikacji odporności ogniowej elementów przeszklonych}

Z przedstawionych powyżej zdjęć jednoznacznie wynika, że badania z zakresu odporności ogniowej przeprowadza się na elementach o rzeczywistych wymiarach, co oznacza, że trzeba dysponować specjalistycznym piecem, na którym takie elementy można zamontować. Przez wiele lat maksymalne wymiary elementów badawczych nie przekraczały $3 \times 3 \mathrm{~m}$, co oznaczało że najpopularniejsze piece do badań odporności ogniowej elementów pionowych miały właśnie wymiary $\mathrm{w}$ świetle $3 \times 3 \mathrm{~m}$, a w przypadku elementów poziomych $3 \times 4 \mathrm{~m}$. Badanie takich elementów, pozwalało na rozszerzanie wyników zastosowania na znacznie większe konstrukcje [19], [20], jakie spotykano w realnych budynkach. Rozwój wiedzy z tego zakresu, poparty latami doświadczeń badawczych wykazały, że nie była to słuszna droga, ponieważ wielkość badanego elementu przeszklonego, układ przeszklonych paneli, ich rozmiary i proporcje mają znaczący wpływ na osiągany wynik w badaniu.
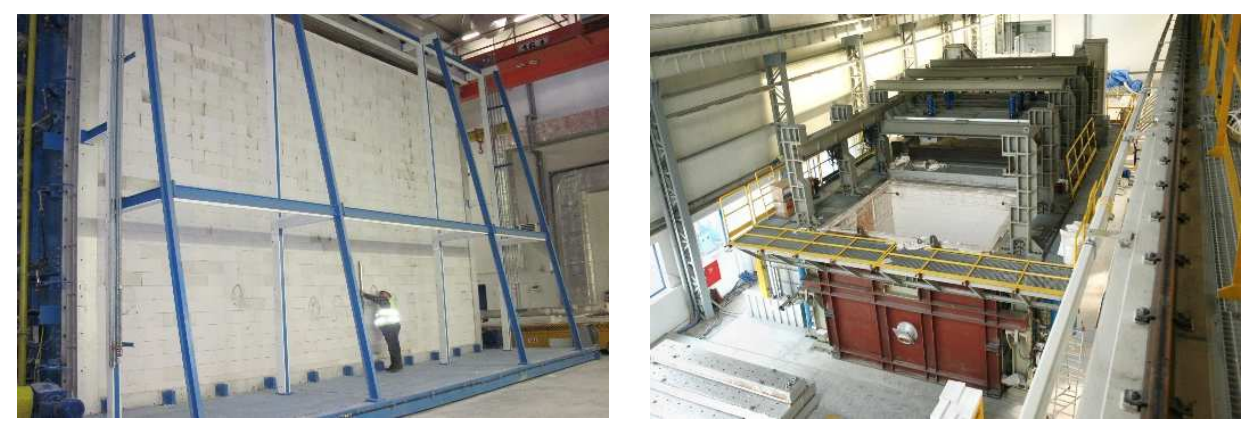

Rys. 4. Po lewej: piec pionowy o wymiarach $7 \mathrm{~m}$ x $10 \mathrm{~m}$ (wysokość $\mathrm{x}$ szerokość); po prawej: 3 komorowy piec do badań głównie elementów poziomych 4,3m x 11,35 m. Autor: ITB

Fig. 4. Left: vertical furnace dimensions of: $7 \mathrm{~m}$ x $10 \mathrm{~m}$ (height $\mathrm{x}$ width); right: 3 chamber furnace, mainly for horizontal elements testing: 4,3 m x 11,35 m. Author: ITB 
Zmiany w normach badawczych, klasyfikacyjnych oraz dokumentach związanych, wymusiły konieczność budowania większych pieców. W wielu laboratoriach badawczych powstały piece o większych wymiarach np. IBS Austria - 9m x 4m (wysokość x szerokość); Pavus Czechy - 6m x 6m; CSTB Francja $12 \mathrm{~m} \times 3,5 \mathrm{~m}$; Fires Słowacja - 5m x 5m; IBMB Braunschweig Niemcy $5 \mathrm{~m} \times 5 \mathrm{~m}$; ITB Polska - 3,7m x 3,7m; 4,5m x 5m, 7m x 10m oraz piec do badań elementów poziomych 4,3m x 11,35 m (szerokość x długość), rysunek 4. i 5.
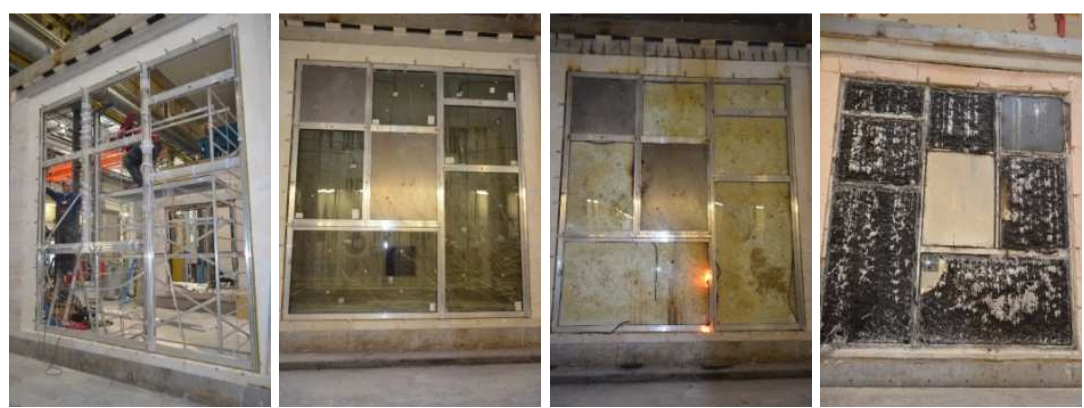

Rys. 5. Montaż elementu przeszklonego, widok przed, w trakcie i po badaniu na piecu o wymiarach $4,5 \mathrm{~m} \times 5 \mathrm{~m}$. Autor: ITB

Fig. 5. Mounting of glazed partition, view prior to the test; during the test and after the test on the furnace dimensions of $4,5 \mathrm{~m}$ x $5 \mathrm{~m}$. Author: ITB

Nieco inaczej wygląda wyposażenie do badania poziomych elementów przeszklonych - stropy, świetliki. W tym wypadku dodatkowo weryfikuje się nośność ogniową, co oznacza, że element badawczy należy obciążyć do założonego poziomu wytężenia, rysunek 6 . W przypadku elementów przeszklonych zazwyczaj wykorzystuje się obciążniki, które przez cały czas trwania badania znajdują się na elemencie lub są od strony nagrzewanej do niego podwieszone. Oznacza to, że badanie elementów poziomych jest bardziej niebezpieczne od badania elementów pionowych, z uwagi na fakt możliwości wpadnięcia zniszczonego elementu do wnętrza pieca.
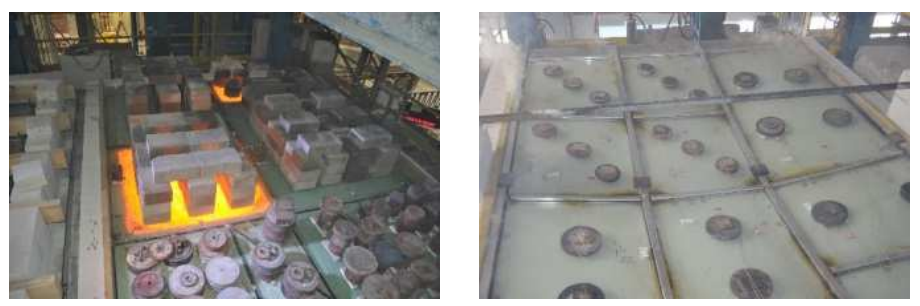

Rys. 6. Widok obciążonych grawitacyjnie poziomych elementów przeszklonych podczas badania odporności ogniowej. Autor: ITB

Fig. 6. The view of gravity loaded horizontal glazed elements during fire-resistance tests. Author: ITB 
Przedstawione na zdjęciach badania, z uwagi na powtarzalność zawsze odbywają się według ściśle określonego scenariusza. Oczywiście można założyć sobie dowolną zależność pomiędzy czasem i przyrostem temperatury, niemniej nie będzie to wtedy badanie normowe. Norma [21] dopuszcza kilka scenariuszy, np. krzywa powolnego nagrzewania (pożar tlący się), pożar „semi-naturalny”, oddziaływanie temperatury o stałym poziomie np. stosowane przy badaniu drzwi dymoszczelnych [22], [23], przy czym najważniejsze z nich dla elementów przeszklonych są:

- standardowa krzywa temperatura-czas (pożar rozwinięty), który stosuje się przy opisie w pełni rozwiniętego pożaru w pomieszczeniu, oraz tzw.

- krzywa zewnętrzna która ma zastosowanie przy opisie w pożaru ściany zewnętrznej kiedy ogień wydostaje się przez okno lub zwykłego pożaru zewnętrznego (rys. 7.).

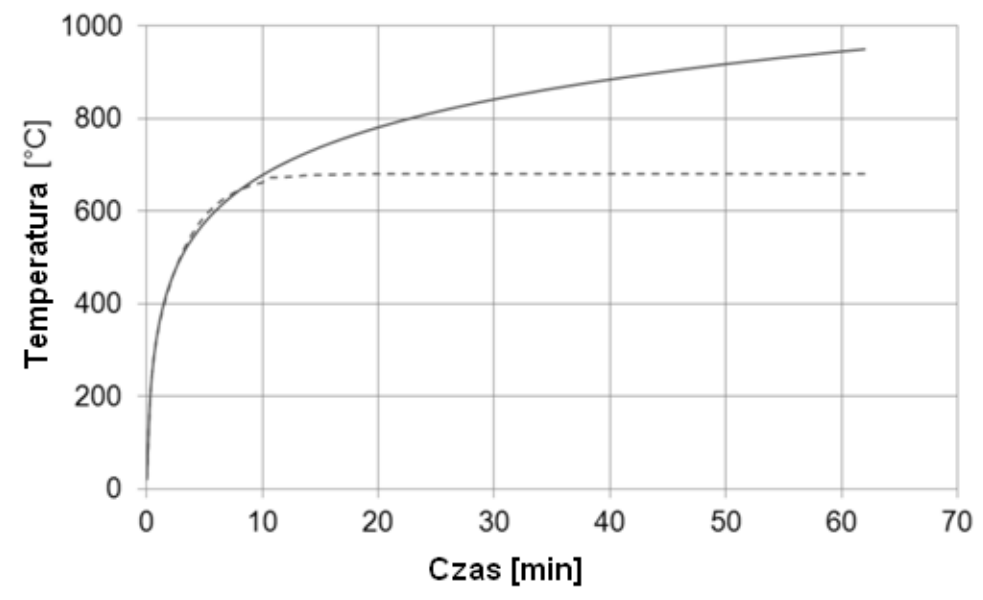

Rys. 7. Podstawowe krzywe nagrzewania. Linia ciągła - krzywa standardowa, linia przerywana - krzywa zewnętrzna. Autor: ITB

Fig. 7. Basic heating curves: Solid line - standard temperature/time curve; dashed line: external curve. Author: ITB

\section{Elementy wpływające na odporność ogniową przegród przeszklonych}

Wśród bardzo wielu czynników, wpływających na wynik badania odporności ogniowej elementów przeszklonych, trzy czynniki odgrywają najistotniejszą rolę. Pierwszym z nich jest dobór właściwego przeszklenia oraz sposób jego zamocowania. Generalnie spotyka się dwa podstawowe typy przeszklenia. Pierwsze z nich składa się z wielu warstw specjalnej folii lub żelu (zazwyczaj twardego), występujących w niewielkich grubościach, usytuowanego pomiędzy dwoma szybami typu float. W tym wypadku uszkodzenie jednej $\mathrm{z}$ warstw 
ogniochronnych, nie eliminuje całego elementu, ponieważ pozostają jeszcze kolejne warstwy. Drugi rodzaj to przeszklenie składające się z grubej, nawet ponad $2 \mathrm{~cm}$ warstwy żelu (zazwyczaj miękkiego) pomiędzy warstwami szkła typu float. Warstwa żelu w wysokiej temperaturze twardnieje zapewniając odporność ogniową. Należy zwrócić uwagę, że do czasu utwardzenia - krystalizacji żelu, narażony jest on na uszkodzenia mechaniczne (tafla szklana od strony nagrzewania zazwyczaj odpada w 2-3 minucie oddziaływania krzywej standardowej). Najczęściej rozbieżności dotyczą grubości zestawu szklanego, w tym elementów ogniochronnych. Nawet niewielka różnica, 2-3 mm, w grubości żelu może dać diametralnie niższą klasę odporności ogniowej badanego elementu w stosunku do deklarowanej. Bezwzględnie należy więc weryfikować grubość szkła, w tym poszczególnych warstw, dostarczanych na budowę. Przykłady zachowania szkła ogniochronnego podczas badania odporności ogniowej przedstawiono na rysunku 8.
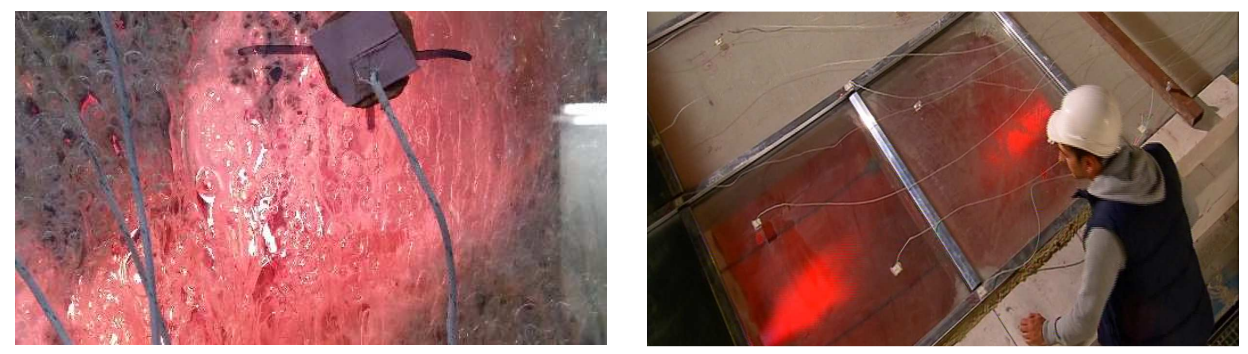

Rys. 8. Widok szkła ogniochronnego podczas badania. Po prawej widoczne zmatowienie części przeszklenia. Autor: ITB

Fig. 8. The view of fire resistant glazing during testing. On the right there is visible tarnishing of the part of the glazing

Kolejnym ważnym elementem jest wypełnienie profili. W większości przypadków stosuje się profile aluminiowe lub stalowe, sporadycznie drewniane. Profile metalowe są dobrymi przewodnikami ciepła, dlatego też należy je wypełniać różnego rodzaju izolatorami, utrudniającymi przenikanie ciepła ze strony nagrzewanej na stronę nienagrzewaną i wzrost temperatury jej powierzchni. Najczęściej stosuje się wypełnienia gipsowe, silikatowo-cementowe, krzemianowo-wapniowe lub z wełny mineralnej. $\mathrm{Z}$ uwagi na komorową budowę profili, wypełnia się komorę środkową, skrajne lub wszystkie. W gotowym elemencie trudno jest zweryfikować miejsce i jakość wypełnienia, a jak wskazują dane $\mathrm{z}$ badań zamieszczone na rysunkach 9. i 10., jest to bardzo istotny czynnik wpływający na uzyskane wyniki badań, podobnie jak rodzaj zastosowanej krzywej nagrzewania [7], [24]-[26]. 

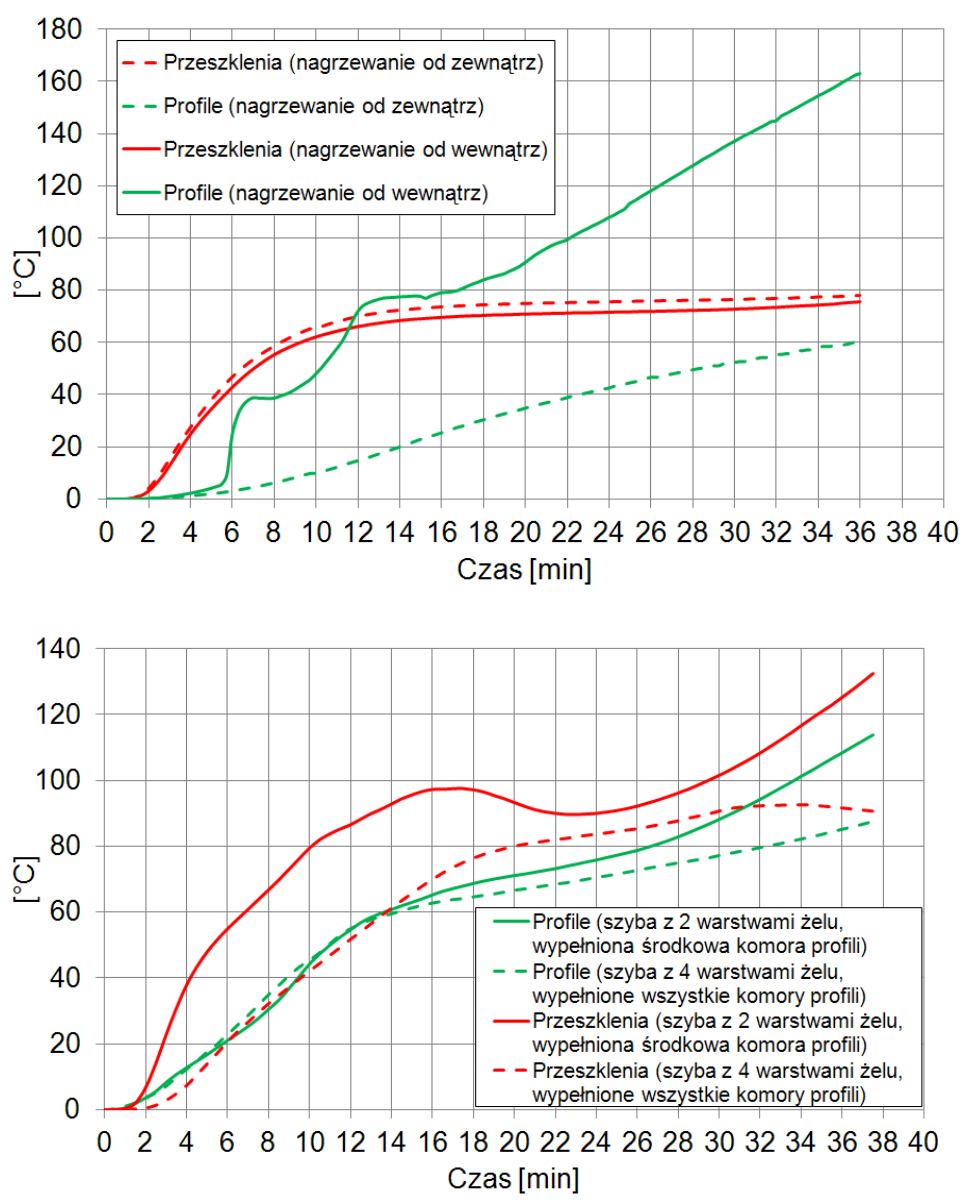

Rys. 9. a) porównanie średnich przyrostów temperatury na profilach i przeszkleniach aluminiowo-szklanej ściany osłonowej w zależności od warunków nagrzewania; b): porównanie średnich przyrostów temperatury na profilach i przeszkleniach aluminiowo-szklanej ściany działowej w zależności od stopnia wypełnienia profili oraz rodzaju zastosowanego przeszklenia (źródło: Archiwum ITB)

Fig. 9. a) comparison of the average temperature rise on profiles and glazing of the aluminium glazed curtain wall depending on the heating conditions, b) comparison of the average temperature rise on profiles and glazing of the aluminium glazed partition wall depending on the degree of filling of the profiles and the type of glazing used (source: ITB Archives) 

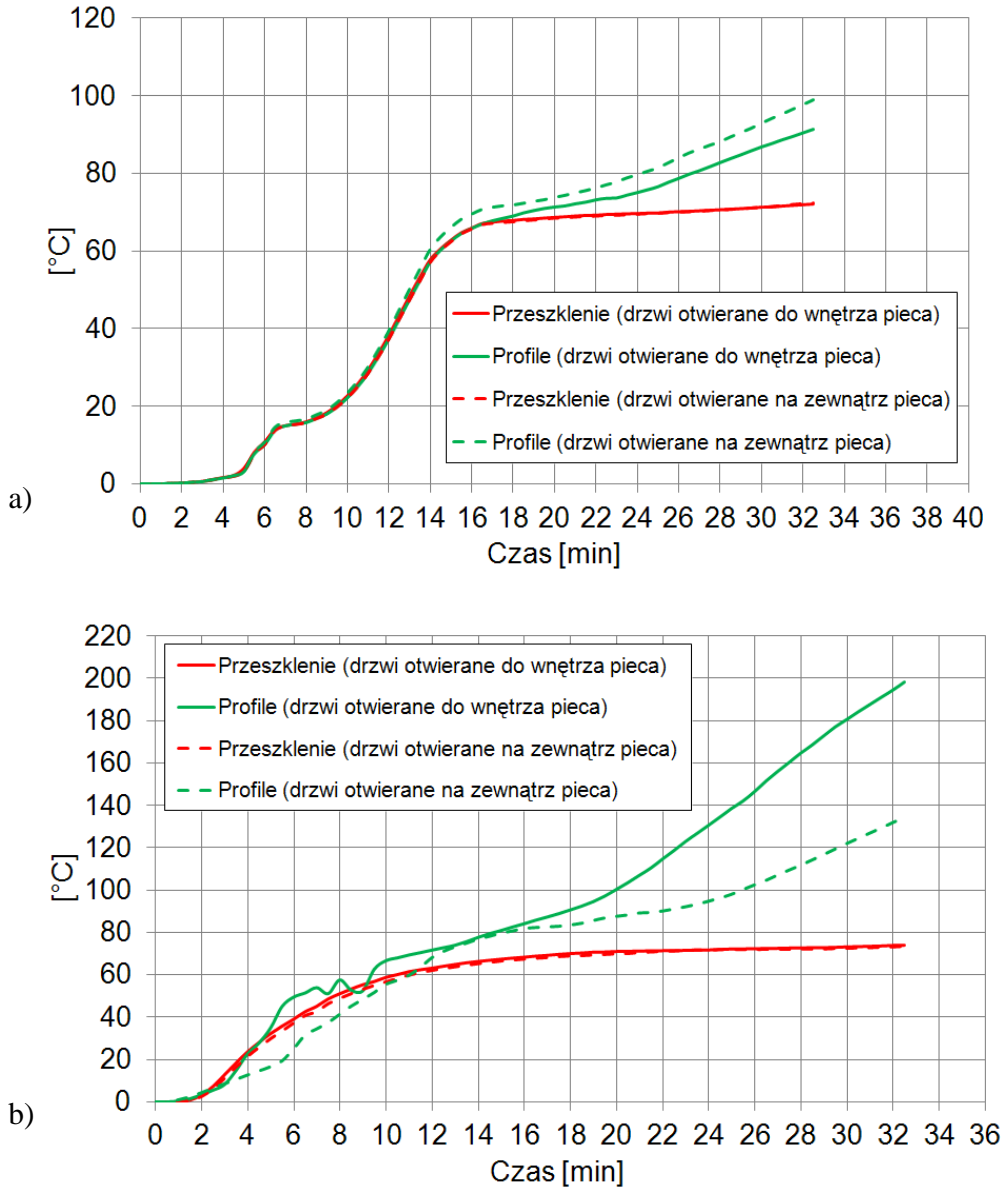

Rys. 10. a) porównanie przyrostów temperatury na profilach oraz przeszkleniach aluminiowych drzwi rozwieranych w zależności od kierunku oddziaływania ognia; b) porównanie przyrostów temperatury na profilach oraz przeszkleniach stalowych drzwi rozwieranych w zależności od kierunku oddziaływania ognia (źródło: Archiwum ITB)

Fig. 10. a) comparison of the average temperature rise on profiles and glazing of the aluminium glazed, hinged doors depending on the side of fire exposure; b) ) comparison of the average temperature rise on profiles and glazing of the steel glazed, hinged doors depending on the side of fire exposure (source: ITB Archives)

Trzecim z wymienionych czynników mających bardzo istotny wpływ na skuteczność działania przeszklonej przegrody ogniochronnej, jest poprawność jej montażu do konstrukcji wsporczej. Wielokrotnie zdarzało się, że prawidłowo wykonana np. ściana czy drzwi o odporności ogniowej, w wyniku nieprawidłowego wbudowania w konstrukcję np. ścianę murowaną, nie stanowiły właściwej 
bariery dla ognia. Potwierdziły to badania wykonane na zlecenie nadzoru budowlanego, gdzie zauważono, że jakość montażu na podstawie dostarczonej do drzwi przeciwpożarowych instrukcji, często jest niewystarczająca. W przypadku badań ogniowych, w odróżnieniu od badań mechanicznych, nie zawsze usztywnienie konstrukcji poprzez mocniejsze przymocowanie do konstrukcji wsporczej jest działaniem wskazanym. Działające temperatury bliskie $1000^{\circ} \mathrm{C}$ powodują tak dużą deformację elementu, że bywają przypadki, kiedy mocowanie do konstrukcji wsporczej jest wyrywane $\mathrm{z}$ fragmentem ściany, umożliwiając przedostanie się ognia na drugą stronę. Jedynie prawidłowy, często trudny i nieintuicyjny montaż przez doświadczoną i przeszkoloną ekipę monterską, jest gwarantem prawidłowej pracy przeszklonej przegrody podczas pożaru.

\section{Wnioski}

Pomimo, że statystycznie średni lub duży pożar budynku, w stosunku do wolumenu budynków w Polsce, jest mało prawdopodobny, to niemalże codzienne doniesienia prasowe nie pozwalają zapomnieć o tragediach, jakie z sobą niesie ogień. Od wielu lat staramy się wznosić budynki, głównie z materiałów niepalnych, wyjątkiem jest drewno, niemniej jednak przechowywane w budynkach materiały, jego wyposażenia, media, itp. powodują, że nie możemy wykluczyć powstania pożaru w cyklu życia budynku. Nowoczesna architektura bardzo obficie czerpie z rozwiązań zapewniających optymalne wykorzystanie światła naturalnego, do czego doskonale nadaje się szkło. Zwykłe szkło, pomimo że jest materiałem niepalnym, nie stanowi trwałej przegrody dla ognia, dlatego w miejscach, gdzie jest to wymagane, bardzo powszechnie stosuje się przeszklone elementy o odporności ogniowej. Dotyczy to wielu elementów budowlanych, ale najczęściej szkło ogniochronne wykorzystywane jest do wykonywania oddzieleń przeciwpożarowych tj. ściany działowe, drzwi, ściany osłonowe (elewacyjne), świetliki, rzadziej całe dachy i stropy. W każdym wypadku należy pamiętać o stosowaniu rozwiązań systemowych, gdyż nawet niewielka zmiana np. wymiana szkła na inne, również ogniochronne, ale nie przebadane z danymi profilami, może spowodować, że nie zostanie zachowana integralność elementu w sytuacji wyjątkowej jaką jest pożar. Nie ma w zasadzie szansy innej niż niszczące badanie, weryfikacji odporności ogniowej elementu, dlatego należy przykładać bardzo dużą staranność, znacznie wyższą niż powszechnie obserwowana w budownictwie, do montażu przeszklonych elementów mających zapewnić nam bezpieczeństwo i możliwość ewakuacji w sytuacji wystąpienia pożaru w budynku.

\section{Literatura}

[1] Sędłak B., Kinowski J., Izydorczyk D., Sulik P.: Fire resistance tests of aluminium glazed partitions, Results comparison, Appl. Struct. Fire Eng., p. 472-477, Jan. 2016. 
[2] Sędłak B., Sulik P.: Badanie i klasyfikacja w zakresie odporności ogniowej przeszklonych ścian działowych według wymagań nowego wydania normy badawczej. Cz. 1., Świat szkła, vol. 21, no. 2, pp. 38-40, 42, 2016.

[3] Sędłak B., Sulik P.: Badanie i klasyfikacja w zakresie odporności ogniowej przeszklonych ścian działowych zgodnie $\mathrm{z}$ wymaganiami nowego wydania normy badawczej. Cz. 2., Świat szkła, vol. 21, no. 5, pp. 27-28, 30-34, 2016.

[4] Sędłak B.: Bezpieczeństwo pożarowe przeszklonych ścian działowych, Świat szkła, vol. 20, no. 5, pp. 34-40, 2015.

[5] Kinowski J., Sędłak B., Sulik P.: Large glazing in curtain walls - Study on impact of fixing methods on fire resistance, MATEC Web of Conferences, 2016, vol. 46, p. 05004.

[6] Sulik P., Sędłak B., Kinowski J.: Study on critical places for maximum temperature rise on unexposed surface of curtain wall test specimens, MATEC Web of Conferences, 2016, vol. 46, p. 02006.

[7] Sulik P., Kinowski J., Sędłak B.: Fire resistance of aluminium glazed curtain walls, Test results comparison depending on the side of fire exposure, Appl. Struct. Fire Eng., p. 478-483, Jan. 2016.

[8] Sędłak B.: Badania odporności ogniowej przeszklonych ścian osłonowych wg nowego wydania normy PN-EN 1364-3, Świat szkła, vol. 19, no. 7-8, pp. 49-53, 2014.

[9] Izydorczyk D., Sędłak B., Papis B., Turkowski P.: Doors with Specific Fire Resistance Class, Procedia Eng., vol. 172, pp. 417-425, 2017.

[10] Izydorczyk D., Sędłak B., Sulik P.: Thermal insulation of single leaf fire doors, Test results comparison in standard temperature-time fire scenario for different types of doorsets, Appl. Struct. Fire Eng., p. 484-489, Jan. 2016.

[11] Sulik P., Sędłak B.: Wybrane zagadnienia związane z drzwiami przeciwpożarowymi, Inżynier Budownictwa, no. 11, pp. 90-97, 2015.

[12] Sulik P. Sędłak B.: Odporność ogniowa drzwi z dużymi przeszkleniami, Świat szkła, vol. 20, no. 3, pp. 38-42, 2015.

[13] Izydorczyk D., Sulik P., Kinowski J., Sędłak B.: Fire resistance of timber windows - Part II: Technical solutions and test results, Ann. Warsaw Univ. Life Sci. - SGGW For. Wood Technol., vol. 92, pp. 113-116, 2015.

[14] Kinowski J., Sędłak B., Sulik P., Izydorczyk D.: Fire resistance of timber windows - Part 1: Test procedure and classification, Ann. Warsaw Univ. Life Sci. - SGGW For. Wood Technol., vol. 92, pp. 183-187, 2015.

[15] Roszkowski P., Sędłak B.: Badania odporności ogniowej poziomych elementów przeszklonych, Świat szkła, vol. 19, no. 12, pp. 46-51, 2014.

[16] Roszkowski P., Sędłak B.: Metodyka badań odporności ogniowej dachów przeszklonych, Świat szkła, vol. 16, no. 6, pp. 50-52, 2011.

[17] Laskowska Z., Borowy A.: Szyby w elementach o określonej odporności ogniowej, Świat szkła, vol. 20, no. 12, pp. 10-15, 2015.

[18] Zieliński K.: Szkło ogniochronne, Świat szkła, vol. 1, pp. 9-11, 2008.

[19] Kinowski J., Sędłak B., Sulik P., Izydorczyk D.: Fire resistance glazed constructions classification, Changes in the field of application, Appl. Struct. Fire Eng., p. 460-465, Jan. 2016. 
[20] Laskowska Z., Borowy A.: Rozszerzone zastosowanie wyników badań odporności ogniowej ścian działowych przeszklonych wg PN-EN 15254-4, Mater. Bud., vol. 7, pp. 62-64, 2012.

[21] EN 1363-1:2012 Fire resistance tests. General requirements.

[22] Sędłak B., Frączek A., Sulik P.: Wpływ zastosowanego rozwiązania progowego na dymoszczelność drzwi przeciwpożarowych, Mater. Bud., vol. 1, no. 7, pp. 26-29, Jul. 2016.

[23] Sędłak B.: Przeszklone drzwi dymoszczelne - badania oraz klasyfikacja w zakresie dymoszczelności, Świat szkła, vol. 18, no. 4, pp. 35-38, 2013.

[24] Sędłak B., Sulik P., Roszkowski P.: Fire resistance tests of aluminium glazed partitions with timber insulation inserts, Ann. Warsaw Univ. Life Sci. - SGGW For. Wood Technol., vol. 92, pp. 395-398, 2015.

[25] Kinowski J., Sędłak B., Sulik P.: Izolacyjność ogniowa aluminiowo - szklanych ścian osłonowych w zależności od sposobu wypełnienia profili szkieletu konstrukcyjnego, Izolacje, vol. 20, no. 2, pp. 48-53, 2015.

[26] Sędłak B., Kinowski J., Borowy A.: Fire resistance tests of large glazed aluminium curtain wall test specimens - Results comparison, MATEC Web of Conferences, 2013, vol. 9, p. 02009.

\section{SELECTED ASPECTS OF FIRE RESISTANCE EVALUATION OF GLAZED FIRE PROTECTION ELEMENTS}

\section{S u m m a r y}

The increasing use of glass in modern construction has its justification. It is a material that allows usable surfaces to maximize the use of daylight, and modern technologies allow for the elimination of adverse atmospheric influences while providing the necessary comfort and intimacy. In addition, modern glass facades also allow for energy-efficient solutions, including the recovery of solar energy.

Buildings, including glazed elements in addition to normal conditions of use, must also meet fire requirements within the specified range. While many solutions, such as masonry, construction, fire and fire protection requirements are fulfilled in parallel, special solutions should be used for glazed elements to achieve appropriate fire resistance class, reaction to fire class, smoke control class, or fulfill the requirements for the spread of fire by elements.

Keywords: Fire resistant partition walls, curtain walls, fireproof doors, smoke control doors, glazed partition walls, glazed roofs, fire resistance, smoke control

Przestano do redakcji: 24.04.2017 r.

Przyjęto do druku: 01.09.2017 r. 